\title{
External support to local institutions: providing political leverage to weaker groups, or sustaining traditional relations of power?
}

Nygaard, Ivan

Published in:

European Journal of Development Research

Publication date:

2008

Document Version

Peer reviewed version

Link back to DTU Orbit

Citation (APA):

Nygaard, I. (2008). External support to local institutions: providing political leverage to weaker groups, or sustaining traditional relations of power? European Journal of Development Research, 20(4), 649-665. http://www.tandfonline.com/doi/abs/10.1080/09578810802464938

\section{General rights}

Copyright and moral rights for the publications made accessible in the public portal are retained by the authors and/or other copyright owners and it is a condition of accessing publications that users recognise and abide by the legal requirements associated with these rights.

- Users may download and print one copy of any publication from the public portal for the purpose of private study or research.

- You may not further distribute the material or use it for any profit-making activity or commercial gain

- You may freely distribute the URL identifying the publication in the public portal

If you believe that this document breaches copyright please contact us providing details, and we will remove access to the work immediately and investigate your claim 


\title{
External support to local institutions: providing political leverage to weaker groups, or sustaining traditional relations of power?
}

\author{
Ivan Nygaard, UNEP DTU Partnership \\ Department of Management Engineering, Technical University of Denmark \\ E-mail: ivny@dtu.dk, Phone: +4545335297. \\ Post print version of paper published in \\ The European Journal of Development Research \\ Vol. 20, No. 4, December 2008, 649-665 \\ http://www.tandfonline.com/doi/abs/10.1080/09578810802464938
}

\begin{abstract}
There is a body of literature showing that donor-supported institutions in Sub-Saharan Africa (SSA) are often captured by local elites, but this literature rarely touches upon whether elite capture is contingent on institutions. However, if this is the case, some institutions may provide political leverage for weaker groups, while others may sustain existing or traditional relations of power. The aim of this study of three cases of donor-supported institutions in Burkina Faso is to understand why close relatives of traditional chiefs invest in gaining control over a municipality, while showing only limited interest in gaining control of village groups and the electricity cooperative. The article argues that while local actors are generally attracted by development rents from donor-supported institutions, relatives of traditional chiefs seem to value the symbolic importance of institutions more than economic resources. The study thus enhances our understanding of mechanisms for access to local donor- supported institutions.

Il existe tout un pan de la littérature qui montre que les institutions appuyées par les bailleurs de fonds en Afrique Subsaharienne (ASS) sont accaparées par les élites locales, mais cette littérature se demande rarement si ce comportement dépend ou non des institutions. Si c'est le cas, certaines de ces institutions peuvent cependant permettre à des groupes plus faibles d'exercer une certaine influence politique alors que d'autres maintiennent les rapports de force existants. Le but de cette étude, qui comporte trois études de cas d'institutions appuyées par des bailleurs de fonds au Burkina Faso, est de comprendre pourquoi des parents proches de chefs traditionnels cherchent à prendre le contrôle de la municipalité alors qu'ils ne montrent qu'un intérêt limité pour obtenir le contrôle; des groupements villageois et de la coopérative d'électricité. L'article défend l’idée que bien que les acteurs locaux soient généralement attirés par les rentes de développement liées aux institutions appuyées par les bailleurs de fonds, les parents des chefs traditionnels semblent donner une plus grande importance à la valeur symbolique des institutions qu'aux ressources économiques. L’étude renforce ainsi notre compréhension des mécanismes d'accès aux institutions appuyées par les bailleurs de fonds.
\end{abstract}

\section{Keywords}

Local institutions; decentralization; local government; power relations; external intervention; rural electrification 


\section{Introduction}

The building of local institutions based on imported Western concepts has been central to development aid to West Africa since the beginning of the 1970s (Gentil 1986; Jacob 1994). Over time the scope for local institution-building has gradually widened, and the last 15 years has been strongly linked to decentralization efforts. This has led to the establishment of institutions of local government, such as new municipalities in most West African countries.In many cases it has also led to the privatization of traditional government functions such as provision of water and electricity by establishing new institutions such as user committees or user cooperatives (Ribot 1999; Bierschenk and Olivier de Sardan 2003; Ouédraogo 2003; Manor 2004).

Institutions created or supported by development agencies generally have the immediate aim of serving as vehicles for transfers of development resources in order to pursue a variety of development goals such as erosion control, income generation, literacy training and the provision of health care, water and electricity. Meanwhile, the long-term objective is that these institutions should evolve into local democratic institutions in line with institutional models imported from the West. The vision is that democratic rules conveyed by new institutions will gradually erode traditional norms of leadership based on seniority and norms of favouring kin, ethnic groups and clientelist networks related to the ruling elite (Olivier de Sardan 2004, p. 9). Achieving such objectives is complicated by the fact that externally supported institutions seldom fit into a homogenous social setting without some conflict or power struggles. On the contrary, such institutions open up new arenas for contestation, rivalry and positioning. Often old rivalries are sharpened and fought out and new alliances or power constellations may be formed, challenging old-established social positions of control and power (Bierschenk 1988; Crehan and Von Oppen 1988; Elwert and Bierschenk 1988).

Among donor organizations, there seems to be a generally optimistic attitude regarding what it is possible to achieve by building new decentralized institutions in terms of democracy and pro-poor development (see, e.g., IBRD 1996, p. 151; Donnelly-Roark, Ouedraogo, and Ye 2001, 33), while the academic literature generally presents more pessimistic and nuanced views. Jütting et al. (2005, p. 627) claim that decentralization serves the poor, but only under specific conditions, while Crook (2003, p. 77) insists that 'decentralization is unlikely to lead to more pro-poor outcomes without a serious effort to strengthen and broaden accountability mechanisms at both local and national levels'. A large body of literature shows that beneficiaries of decentralization tend to be wealthier groups, and that in many cases external resources are captured by local elites (Lavigne Delville 1992; Blundo 1994; Mongbo 1994; Diawara 1996; Crook and Manor 1998; Gueneau and Lecomte 1998; Crook and Sverrison 2001; Vedeld 2003; Hårsmar 2004; Nijenhuis 2003; Platteau 2004). This literature, however, does not discuss whether elite capture is contingent on differences in institutions. If this is the case, some institutions may provide political leverage for weaker groups, while others may sustain existing or traditional relations of power.

This article is intended to help fill this gap. ${ }^{1}$ Through empirical research into three cases of institutions in a small provincial town in Burkina Faso, it will show why certain institutions are more prone to capture by local elites than others. More specifically, it addresses the question of why political arenas opened by different types of donor-supported local institutions attract distinct social groups. It will be demonstrated that in this case relatives of traditional chiefs are especially attracted to the new municipality, which symbolically competes with the local chieftaincy institution, but show less interest in village groups and the electricity cooperative, which have symbolic importance of a different kind. Based on this example, the article argues that, while local actors are generally attracted by resources from donor-supported institutions, the symbolic importance of the competing institutions seems to be greater than tangible economic resources, and that this contributes to explaining why the current decentralization process in Burkina Faso brings relatives of traditional chiefs back into office.

In the following section, I will introduce the three cases of institutions being examined here and the concept of arena. I will then present the research methodology and examine the social organization and main social contradictions in the locality being investigated. Against this background, I address 
which motives actors pursue in engaging and participating in the arenas opened up and which social groups participate in specific arenas. These questions are addressed in three subsequent sections dealing with the three empirical cases: village group, municipality and cooperative. The concluding section explores the question of why certain institutions are more prone to elite capture than others.

\section{Local institutions as political arenas}

In this article, with Scott (1995, p. 33) I define institutions as 'cognitive, normative and regulative structures and activities that provide stability and meaning to social behaviour'. This means that institutions such as municipalities, village groups and user cooperatives are partly constituted by a set of formal rules on which they are based, as well as a number of informal rules in respect of cognitive and normative structures. This emphasis on informal rules is especially important in the African context, where formal rules are constantly being negotiated (see, e.g., Berry 1993; Lund 1999), and where informal rules are often more important than formal ones (see, e.g., Bierschenk and Olivier de Sardan 1998, p. 38). ${ }^{2}$

The three cases of institution have been selected as examples of local donor-supported institutions, but with different origins and goals. The first case, village groups, is well known throughout West Africa under the term groupements villageois (Lavigne Delville 1992). In the area studied, village groups have served as important vehicles for development aid during the last 25 years (Buijs 1980; McCall, Fleming, Koussoube, and McPherson 1986; Puget 1999). They have been given a number of functions, such as technology transfer in areas like animal traction, pesticides and fertilizers. Furthermore, they have been used to transfer knowledge, such as enrichment of organic nutrients, anti-erosion measures, literacy training and income- generating activities (e.g. vegetable gardening). They have also been used to pool resources, as with Western cooperative societies, and have run mills for cereals, cereal banks and small distribution centres for subsidized cattle fodder. During the last ten years these groups have increasingly served as 'gate-keeping institutions' for new micro-credit schemes (Puget 1999).

The second case of institution, the 'new' municipality, stems from a decentralization reform of a sort that has been strongly encouraged by donors since the beginning of the 1990s (Sawadogo 2001, pp. 209, 218). In Burkina Faso, this process resulted in the creation of 33 municipalities in the first round in 1995 and in a total of 45 municipalities in 2000. The process is ongoing, and in April 2006 municipal councils were elected in 357 urban and rural municipalities (www.ceni.bf). The municipalities officially serve at least two functions. First, they are intended to transfer administrative functions to lower levels of the state bureaucracy, what is usually called the deconcentration of administrative functions (Rondinelli 1981). This embraces functions such as registration of births, land registration and the management of schools. The intention is also to transfer decisive power to an elected council, which has independent authority over well-defined areas, as well as the authority to collect taxes, what is usually called the devolution of state power. However, in the Burkinabe context, during the field research for this article in 2002 these municipalities mainly served as a means to obtain access to development resources, such as roads, schools, water provision and marketplaces, with the devolution of state power lagging behind (AMBF 2000, p. 33).

The third case of institution is the consumer-owned electricity cooperative, whose main objective is to provide its members with electricity. This type of ownership of electricity companies is new in Burkina Faso, and is one way among others of organising the electrification of rural areas. The donors' objectives, however, are not only to provide townspeople with electricity, but also to establish a new institution, the cooperative electricity society, conceived as a means of the electrification of rural areas on a private basis. This vision is nurtured by the fact that the cooperative society was the institution responsible for a fair part of the electrification of rural areas in such different countries as Denmark, France and the United States (Van der Vleuten 1998; Massé 2004). 
The institutions constituting the three cases are different in a number of ways, and especially in terms of institutional maturity and in their relationship to the state. However, for the purposes of the argument in this article, it is important to emphasize the following common characteristics. These institutions are emerging in a development context, they are strongly supported by development agencies, and they have been 'imported' into the African context in the sense that they are modelled on Western institutions and are different from existing ones. ${ }^{3}$ This article is based on the assumption that externally supported institutions open new 'arenas' for struggle over resources (see, e.g., Bierschenk 1988; Crehan and Von Oppen 1988; Elwert and Bierschenk 1988; IBRD 1996). In this context the concept of an arena refers to 'social locations or situations in which contests over issues, resources, values and representations take place. That is, they are social and spatial locations where actors confront each other, mobilize social relations and deploy discursive and other cultural means for attainment of specific ends' (Long 2001, p. 59).

This means that an arena constitutes a bounded frame or stage where a specific conflict or dispute takes place. The arena thus defines the actors involved and the issues, resources and discourses that are being fought over (Long 2001). This implies that development projects, cooperatives and 'local politics’ are all arenas (Bierschenk and Olivier de Sardan 1997, p. 240). An arena is not necessarily spatially restricted, and only in some cases is it spatially defined, as in the case of a village. When dealing with development interventions, contestation over issues such as resources and values is generally not limited to a spatial setting, but can often involve geographically distinct actors. This implies that, although an arena is defined in terms of confrontation between actors, it does not necessarily involve a face-to-face confrontation. Actors can participate in struggles in different arenas at the same time, and arenas often overlap or are interlocking. What happens in one arena might easily influence an outcome in other arenas (Long 2001).

In the present analysis, the extent of an arena depends on the conflict or resources at stake within it. Institutions such as cooperatives and village groups may constitute arenas in which only members of the institutions are the actors. In these cases, the arena is spatially confined to the town inasmuch as the members live in the town. Election to the municipality constitutes an arena that is spatially much wider than the village and which includes actors from the regional town, the capital and even foreign actors, because political parties in the capital and townspeople abroad (ressortissants) may be important actors too. In this case, the local constituency constitutes a specific arena, as only members of the constituency have the right to vote. This arena is thus spatially defined and is a subset of the wider 'election' arena. Resources are both material (economic) and symbolic. Symbolic resources recall Bourdieu's notion of symbolic capital, which comprises social relations, status, prestige and honour. Symbolic capital, e.g. in terms of honour, can be converted to economic capital at a later stage and vice versa (Bourdieu 1977, pp. 177-183).

Development interventions can be perceived as constituting a special arena, the 'development interface', which is different from other arenas in various ways (see Long 2001). It is characterized by the relative abundance of economic resources, which enables struggles over both economic and symbolic resources (Bierschenk 1988; Crehan and Von Oppen 1988; Elwert and Bierschenk 1988).

\section{Research methodology}

The empirical data presented in this article is based on about six months of fieldwork in 2002 and 2003 in two small towns in northern Burkina Faso. Since only one of the towns, Sebba, had all three types of institution, this article is mainly based on empirical data from there, while findings from the other town, Seytenga, will be used to provide extra support for some of the arguments. Various methods were combined during the empirical research, and the field data gathered were mainly qualitative. Besides observation and participation in daily life in the towns, I used various rural appraisal methods, such 
as transect walks and wealth-ranking. However, a significant amount of data was collected through close to 100 formal semi-structured interviews, which were carried out partly as group interviews and partly as individual interviews with members of the institutions studied and with key individuals in other local institutions. Moreover, detailed inventories of ethnic-group membership, family relationships and clientelist relationships involving major post-holders in the towns were compiled.

\section{Social organization and social contradictions in Sebba}

Sebba is a small town, situated in the northern part of Burkina Faso. The population mainly consists of Fulbe and their former slaves, the Rimaïbe, while a smaller group of Songhay, Hausa and Mossi have moved in since the beginning of the 1970s. ${ }^{4}$ Fulbe culture, however, is still pervasive (Boesen 1999). The common language is Fulfulde, while Islam is the religion of about $98 \%$ of the population.

The town of Sebba has been in existence here for about 200 years, and it is still the centre for the emirate, which was founded when Fulbe herders conquered the sedentary agriculturalist population. The status of the town as the centre of the emirate has played a principal role in the social life of Sebba, partly because the royal family has appropriated resources from the surrounding area, and partly because rivalries between competing factions of the royal family have had important ramifications for social relations in the town. Meanwhile, Sebba's role as an administrative centre attracted attention and interference from the French colonial machine from the start of the twentieth century. Today Sebba has about 5000 inhabitants, and in 1996 obtained administrative status as the capital of the newly created Yagha Province, a status which also led to the formation of a municipality mainly covering the town's spatial area (Loyara, Ouedraogo, and Sanou 2000).

Historical analysis of old conflicts and contradictions in African societies is a valuable entry point for understanding present relationships of power (Irwin 1981). Acknowledging that power relations are neither simple nor static, my historical analysis of power relations in Sebba revealed a pattern of three main social contradictions as important in a historical perspective (Nygaard 2006). The first is the ethnic contrast between the former Fulbe masters and their slaves, the Rimaïbe. Traditionally, the Rimaïbe cultivated, whereas their masters herded. Even after the formal liberation of slaves at the beginning of the last century, this division of labour continued, with the Fulbe maintaining their role as pastoralists and the Rimaïbe that of agriculturalists. In the course of time, and especially after two periods of drought in 1972 - 73 and 1983 - 84, both Fulbe and Rimaïbe have become agropastoralists, and the economic differences between the two groups have become less distinct. While the dominance of the Fulbe over the Rimaïbe is strongly embedded culturally, the Rimaïbe are in many cases economically better off than their former masters (Hampshire 2002, p. 29; Thébaud 2002, p. 220).

The second contradiction is between the ruling and rival factions of the royal family. This cleavage between two branches or factions can be traced back to about 1935, when the colonial power violated the rules of succession to the emirate and enthroned a younger and cooperative brother of the first wife, instead of the eldest but less cooperative brother of the second wife. This created an atmosphere of envy and mistrust between the sons of the first and second wives and, as a consequence, the old compound of the emir was virtually divided into the compound of the newly appointed emir, Baade Amiirou, and the compound of his rival, Baade Karmadji. The struggle between the two factions has since been nurtured and maintained in various arenas, and the cleavage is still important in understanding contemporary power relations in Sebba (Nygaard 2006).

The third historical social contradiction is between the Islamic Hamallist brotherhood and the ruling faction of the royal family. ${ }^{5}$ The Hamallist brotherhood constituted a significant movement of emancipation in the 1940s directed against the colonial power and its collaborators and, although it lost some of its importance after independence, the son of the former Hamallist leader, who was imprisoned by the French in the 1940s, still plays an important role as a centre of political power opposed to the ruling branch in Sebba (Nygaard 2006). 
Since the creation of the first political parties in 1946, these three old contradictions have become visible to a great extent through affiliation to different national political parties. While the ruling faction has generally been linked to the ruling party, the rival faction has mainly supported the opposition. Likewise, while the ruling faction has always been in opposition to the Hamallist movement, the competing branch has maintained its affiliation with the Hamallists and forged strategic alliances with them. Both the political and the religious arenas have linked the local struggle to national politics.

Despite their extent, animosities and contradictions between the former masters and their former slaves have never given rise to direct, organized confrontations between the two groups. Contradictions have rather been embedded in other social and political movements, such as the Hamallist movement, the Sankara revolution and to some extent in affiliations with distinct political parties. ${ }^{6}$

However, these contradictions are penetrated by a web of clientelist relationships between former masters and former slaves, as well as between the ruling branch and a number of Rimaïbe, whose forefathers were entrusted and used as brokers between the royal court and its subjects. ${ }^{7}$ These clientelist relationships are still maintained through exchanges of favours and symbols of belonging, in some cases remaining so strong that the Rimaïbe feel greater loyalty to their former masters than to their own ethnic group, while in other cases the ethnic group identity may be the strongest.

Following this brief presentation of my historical analysis of the main social contradictions involved in this example, I will return to the main questions in this article: the motives for participating in local institutions, and the composition of the social groups that do so. I will address these questions one at a time for the three cases, the village groups, the municipality and the cooperative, before proceeding to offer conclusions. Supported by the observation that close relatives of traditional chiefs are especially attracted to institutions, which symbolically compete with chieftaincy institutions, I will argue that the symbolic importance of competing institutions may be more important than tangible economic resources.

\section{Case I: Village groups}

\section{Motives for participating}

According to the prevailing development discourse, a main argument for supporting village groups is to engage women in income-generating activities (see e.g. McCall et al. 1986; Buijsrogge 1989, p. 157; Danida 2001, p. 60). My research, on the contrary, shows how village groups to a large extent serve as vehicles for access to resources coming from external donors, and that most activities can accordingly be interpreted as mainly symbolic activities serving to maintain relations to donors rather than to generate incomes (Nygaard 2006). In this section, I will provide some examples substantiating this argument.

First, it is obvious that motives for participating in village groups are individual and varied. This means that, while access to donor resources seems to be a dominant motive, there are obviously also other motives at work, such as the social and political community and the attraction of symbols of modernity (Crewe and Harrison 1998, p. 168). Secondly, motives are contingent on one's position in these groups, i.e. leader, committee member or ordinary member. How motives depend on positions is illustrated by an excerpt from an interview with a village group secretary, in which she explains why the village group has abandoned a vegetable gardening project around an artificial waterhole (boulis):

Madame [Bâ] has, during the campaign, given 15,000 FCFA to clean all this [the garden area] and furthermore she has given 15,000 FCFA to erect the fence. Now she is not free. She can't do it, because she must not leave her house [because her husband died]. Every time when she was... [before], she came to see if the people (les gens) had worked well, but now when she must not go out and because of the lack of water, she has said that she will drop it this year. We will see. (Interview No. 71, 06-02-03, emphasis added) 
First, it is remarkable that the secretary depicts the leader as if she were the embodiment of the village group. It is the leader, not the treasurer or the village group, who gives money for cleaning and a new fence. Like an employer, the leader has the power and decides whether or not the women go to the garden. In this example, therefore, the village group leader is playing a double role. On the one hand, she acts as a development broker, who has established and maintained contact between the donor community and at the village group. On the other hand, she acts as a patron within the group, for which she takes the decisions. This double position as broker and patron can be beneficial for the leader in economic terms, but the position is also an asset that can be exchanged at a later stage for positions in other, more profitable political arenas. The latter is illustrated by the fact that the leaders of most village groups were politicians themselves or close relatives of politicians.

The excerpt further shows that, when the leader is not able to exercise control, other members do not show any interest in gardening or the project. When directly asked, members could not point to any income generation from the project except for their own consumption, which is why they eventually abandoned it. On the other hand, through many years of experience with the donor community, the leader is very knowledgeable about prevailing donor values, and she therefore pushes members to conduct these mainly symbolic activities to demonstrate commitment and entrepreneurship in order to increase opportunities for new projects, to the benefit of both her and her group. Meanwhile, in this case she failed because her husband died, and she was not allowed to leave the house for a while.

My research reveals that the indirect benefits of being connected to a project, the so-called development rent, can be considerable and can easily outweigh the benefits of engaging in riskier income-generating activities. ${ }^{8}$

In the case of village groups, development rents were diverse and comprised subsidized and scarce resources such as cereals for food aid, subsidized cattle fodder and cheap credit, as well as training and study tours, which were remunerated on a per diem basis. Along with this came a not inconsiderable number of illicit resources in terms of unpaid credit, the misappropriation of project resources and the diversion of investments for other purposes. Finally, there were examples of links with the development community, which provided access to jobs for village group members or their families, jobs which, in economic terms, were far more important to the family than sporadic activities in the village groups. It may therefore be a rational choice to engage in highly symbolic activities in order to maintain access to these development rents.

While, during their lifetimes, these village groups had engaged in a number of projects, enduring profitable and income-generating activities were rare. Village groups generally phased out or lost profitable activities such as mills to private enterprises. Similarly, they seldom embarked on activities on their own initiative that competed with existing enterprises in profitable markets, such as mills or cereal banks. This indicates that the locals do not perceive village groups as the best institution to manage profitable activities. On the contrary, engaging in activities such as collective fields, vegetable gardening and even small dairies are important in releasing new donor funding because they are examples of tangible activities on the ground and because they are symbols that reflect donor values such as entrepreneurship, community in work and women's empowerment. Similar examples of how symbolic activities ensure a continuing flow of resources are depicted by Puget (1999), who conducted research in the same region of Burkina Faso, and in a body of literature from SSA on the same subject (see e.g. Blundo 1994; Floquet 1994; Mongbo 1994; Crewe and Harrison 1998; Laurent 1998).

\section{Who participated?}

According to the formal rules, village groups should be inclusive institutions open to all citizens in the town. In much of the donor literature, village groups are implicitly described as organizations representing the whole village or small town. ${ }^{9}$ My own research, however, reveals that the formal rules have little importance in this case. In practice, village groups are mainly exclusive institutions, and membership follows local norms of community such as families, factions, ethnic groups or 
clientelist networks. This observation is not new and has been described in other investigations in the field (Blundo 1994; Jacob 1994; Puget 1999). My point here, however, is that this exclusion works especially to the detriment of the poorest strata of the population, who have poor networks as well as less time to engage in 'risk-reducing' institutions such as village groups.

I found that the poorest are excluded at two levels. First, it is the middle-income and richest groups that participate in village groups. In Sebba, the families dominating the four village groups subject to investigation were perceived as belonging to the medium- and high-income groups. These groups were also among the most active in the sense that they had been connected to the aid system and had received funding and carried out activities. The sporadic information available about the 'less active' or dormant groups in Sebba indicates that village groups, which mainly consisted of people from the poorest and most marginalized strata, had not been able to obtain funding because they had weaker connections to the aid system and in some cases were subject to ethnic exclusion.

Secondly, the poorest strata within the village groups seemed to benefit less than the others. The most profitable activities undertaken by members of village groups in the research area were access to loans and to cheap cattle fodder. My research shows how the poorest people within the group are excluded from access to loans, because they are seen as being unable to pay them back. Also, the poorest do not possess cattle, so they do not benefit from the cattle fodder. Thus, as Engberg-Pedersen also shows (2002, p. 178), the poorest are often those who are least suited to exploiting the benefits provided by village groups.

I also investigated how the historical contradictions between the Fulbe and the Rimaïbe and between the ruling and rival factions of the royal family have influenced affiliation to village groups. The general picture was that people who had not traditionally been in power saw the village groups as an emerging opportunity to exert some economic and political leverage, while the ruling faction of the royal family hardly showed any interest in them. One village group, for example, almost exclusively comprised members from one rival branch of the royal family, while other groups consisted of people from a group of wealthy and former entrusted Rimaïbe in collaboration with Fulbe and non-Fulbe newcomers. Because of their strong position in other political arenas, the ruling faction, and especially its oldest segments, seems to have found the benefits of engaging in village groups to be less than the inconvenience. They use what Engberg- Pedersen (2002, p. 177) has termed 'the strategy of evasion', i.e. they have chosen to protect themselves from the implicit social and political implications of such interventions.

Although the younger segments of the ruling faction seem to be showing an increasing interest in accessing their share of development rents, the general picture remains that the 'middle' social group, consisting of newcomers, former slaves, women and nobles from rival branches of the royal family, are mainly attracted by village groups, while the poorest are generally excluded.

\section{Case II: The municipality}

\section{Motives for participating}

The first election to the municipal council in Sebba in 2000 turned out to be a big social and political event. The campaign was colourful, and impressive resources were mobilized. The themes in the election campaign mainly concerned who would be best positioned as a development broker to achieve donor funding for infrastructure projects, but underlying this, the election mainly centred on which of the two rival factions of the royal family would be able to place their candidate in office as mayor. Since 1935, the two factions had in various ways fought for control over the emirate, of which the new municipality was seen as a 'modern' version. ${ }^{10}$ The mayor, like the emir, was perceived as 'chief of the town', and although belonging to two institutions which, according to the formal rules, are very different, the position of mayor was honourable and on a symbolic level comparable to the position of 
emir.

Ethnicity, belonging to the two competing factions within the royal family and religious affiliation to the Hamallist brotherhood were still markers of identity that played significant roles in patterns of affiliation to different political parties. Political programmes, on the other hand, had little importance, and, as I also found in my second research locality, affiliation to parties was to a large extent structured along lines of kin and factions, and nurtured through clientelist relations with political leaders (see also Maïga 2004, p. 86). With a number of exceptions, the ruling party, the CDP, was led by the ruling faction, Baade Amiirou, while the main opposition party, the CDF, was led by the competing faction, Baade Karmadji. While these two parties were in direct opposition to each other in the factual competition to win back the emirate, a third party, the PAI, mainly led by a group of the emir's former entrusted Rimaïbe and other wealthy Rimaïbe, were in an intermediate position, seen in this perspective. Leaders were non-Fulbe and from an ethic perspective were in opposition to both the ruling and the rival factions. In previous parliamentary elections, however, this social group had formed strategic alliances with the rival branch in confronting the ruling faction. While there may be many reasons for such alliances, one seems to be the historical legacy of the Hamallist movement, which embraced both the rival faction and the Rimaïbe in their struggle with the ruling faction.

Thus, symbolic resources were obviously important at the local level. However, in the wake of the Zongo affair, ${ }^{11}$ when the ruling party had been weakened nationally (Hagberg 2002), it was also of great symbolic importance for the ruling party to defeat the opposition in municipal elections.

\section{Who participated?}

Sebba had historically been a stronghold of the opposition, and therefore the result of the election was a surprise. The ruling party, the CDP, came out as the winner with eight seats, while the CDF and PAI won four and three seats respectively. There are several factors that may explain this. In the light of the importance of regaining the emirate, the fact that the elected mayor was the son of the former emir seems to have been an important asset in his bid to get elected. ${ }^{12}$ Secondly, the fact that he had been working as a prefet for most of his life was also an advantage in trying to convince people that he was well positioned to influence the government and donors to bring new projects to Sebba. Thirdly, better access to government resources seemed to be important. Both the ruling party and the opposition had good connections to well- placed townspeople in the capital, and both were directly and indirectly trying to buy votes, either through promises of better positions, or through direct distribution of 'envelopes'. However, there was no doubt among those I interviewed in Sebba that the ruling party had better access to resources it could distribute than the opposition, and that the quantity of distributed resources was important in explaining its victory. Independently of the reasons, however, the result of the first election in Sebba was a clear victory for the ruling branch of the royal family, as the position as mayor and other influential positions were occupied by relatively old Fulbe men who belong to the ruling branch.

Of course, some patterns are observable that break with this firm picture. Although the Fulbe obtained the most important positions in the council, the Rimaïbe won the most seats, and although most councillors were men, one woman managed to be elected. Similarly, although the older generation obtained the most important positions, representatives of the young generation also won influential positions, and there was an almost uniform distribution of age within the council. These observations could be signs of a gradual change in power relationships, but upon further examination it appeared that the younger generation in the council were either dependent on family connections to the ruling faction, as in the case of the son-in-law of the mayor, or involved in historical clientelist relationships between Fulbe and Rimaïbe families, as in the case of the young opposition leader, the son of a former entrusted Rimaïbe.

In this case, therefore, the new institution, which was supposed to give democratic leverage to the weaker groups, seems instead to have reinforced the old power relations and given office to close 
relatives of the royal family and its clientele. To the extent that the municipality will receive access to external development resources, these resources will bring legitimacy to continued rule by these existing elites and sustain the options for elite capture rather than the contrary.

This conclusion is in line with other research on municipal elections in Burkina Faso, which shows two interrelated patterns (Otayek 1995, 1999; Maïga 2004). One is that elected mayors have close ties of kinship with traditional chiefs, and the other is that local elections are in no way a local affair, and that ressortissants return from national and international careers to be elected mayors of their home towns. Because national politicians are often the close kin of traditional chiefs, these patterns are frequently related.

\section{Case III: The electricity cooperative}

\section{Motives for participating}

The electricity cooperative was a demonstration project conceived by Danida. ${ }^{13}$ In the project document for Danida's energy sector programme, the local population were seen as the decision- makers in the project and were to take decisions on the types of electrical systems to be implemented, types of management systems and size and demarcation of the intervention area (Danida 1999, p. 17). Under these circumstances, there were various good reasons for people to participate in the political arena constituted by the cooperative and to be members of the committee. Being a committee member in the cooperative would provide opportunities to control important resources and to influence the initial plans for and future expansions of the electricity grid. Seen from the mayor's perspective, gaining control might bring some legitimacy to the municipality, inasmuch as access to electricity might be seen as a benefit achieved by the municipality.

Taking the colourful and fiercely fought election campaign for the municipality into account, it was therefore surprising that there was no election campaign for the cooperative. In practice the committee for the electricity cooperative was elected according to a consensus made before the donor's representatives showed up for the constitutive assembly. According to interviews, this approach was taken mainly because the mayor and other local people were afraid that an open election would demonstrate to the donors the high level of conflict in the town and thus place financing of the project at risk. Other explanations may be added to explain why competition for leadership of the cooperative seems to have been less fierce than for the leadership of the municipality.

First, the position of leader of the cooperative may be considered less prestigious than that of mayor. As one informant expressed it, 'to be mayor is very honourable. Very honourable. But to participate in the cooperative, that is to arrange, to be kept occupied'. This opinion indicates that, while being mayor in Sebba was a question of honour and of regaining the emirate, the position of head of the electricity cooperative was seen as ordinary work, or maybe even as a form of occupational therapy for former leaders. The prestige of being on the committee may have been reduced because of a deeper resistance to what are perceived of as the 'institutions of aid' (Engberg-Pedersen 2002, p. 177). In contrast to the municipality, the cooperative might be related to the local narrative of cooperative institutions, which is mainly a narrative of suppression, control and hidden agendas (Nygaard 2006).

A second explanation may be that political parties were not involved in the election. As a result, there was neither an organization to finance a campaign, nor any tradition of sustained public campaigning for such a position. While election campaigns were held like football matches, with supporters on both sides voicing their support, elections to committees followed local norms of decision-making taken by consensus among a small group of notables (Soumane and Bonou 2001, pp. 18 - 20; Hahonou 2006). This does not suggest that negotiations and struggles were absent, but rather that positions were essentially negotiated among a limited group of notables.

A third explanation could be that there are low expectations of one's ability to exert real influence 
in donor-supported committees. While the position of mayor seems to embody symbolizations of autocratic customary power, the experience of participation on user committees for all the different types of donor-supported infrastructure, such as wells, health centres, school boards, marketplaces and saving banks (caisses populaires), has lowered people's aspirations as to the possibilities of influence (Manor 2004). The present example also contributed to such worries. In spite of the written intentions, in practice the project implementation turned out to be a top-down process, mainly implementing a predefined electrical system, a predefined management system (the cooperative) and an intervention zone presented to the committee members as an optimal solution for both technical and economic reasons. So in this case, as so often before (see e.g. White 1996; Michener 1998; Mosse 2001), for the donors, participation legitimized predefined solutions, while for the population it was mainly a means of being included as consumers in the electricity project.

\section{Who participated?}

In Sebba, the committee of the cooperative seemed to be 'wisely' composed by the inclusion of representatives of the ruling faction, Baade Amiirou, the rival faction, Baade Karmadji, and the group of entrusted and wealthy Rimaïbe. The committee also had representatives of the three political parties. The mayor, however, had ensured his influence, and there was a high degree of overlap between members of the municipal council and of the electricity cooperative. The mayor was president, and the first deputy mayor was general secretary. The son-in-law of the mayor, who was the leader of the finance commission in the municipality, was chair of the grid committee. However, while the ruling and rival factions both had representatives on the committee, the former held the powerful positions of president and general secretary, while the rival faction only held one important position, that of chair of the grid committee. Other important positions, such as vice-president and treasurer, were allocated to two relatively young but dynamic individuals who were descended from the group of wealthy Rimaïbe.

The committee members were a mixture of various professions. The president and the general secretary (i.e. the mayor and his deputy) were retired civil servants. Three people, the vice-president, the chair of the grid committee and the chair of the control committee, were all employed at DPEBA, the state agency for literacy training. The treasurer, vice-treasurer and a member of the control committee were businessmen (commerçants), while the only woman involved owned a small restaurant. The last two seats, members on the grid committee and on the control committee, were held by a traditional farmer and by the provincial leader of a farmers' association respectively.

Besides the leader of the farmers' association or CRUS, several people were related to the development arena at different levels. Although my information about the committee members is not exhaustive, it may be illustrated by means of a few examples. One was founder of a local NGO, which sought to promote literacy training. Another was village group leader and yet another the son of an influential Rimaïbe, who was identified as a nucleus of village group activity in the town.

To summarize, the committee mainly consisted of businessmen and well-educated administrators, who straddled the boundaries between the administration, the municipality and the NGO sector. The mayor, who was said to be responsible for selecting the membership of the committee, had created a consensus that was difficult to contest inasmuch as he included representatives of both competing factions and of the wealthy Rimaïbe, but which still left him with control over the committee. The mayor seemed to have the support of his deputy and his son-in-law on the municipal council, and also to a great extent that of the young and dynamic Rimaïbe, who saw their interests in being affiliated to the ruling party, to which most of the committee members also belonged. As Manor (2004) points out, in a context of prevailing clientelist relations, the fact that the committee was in reality appointed by the mayor meant that they owed him something in return. Therefore, in spite of various interests being represented on the committee, the mayor, and thus a representative of the ruling branch of the royal family, seemed to be maintaining a high level of control over the cooperative. 


\section{Conclusion}

This article addresses the overall question of why certain institutions are more prone to capture by local elites than others. It has been shown that the three institutions examined have created three distinct arenas, which have, to some degree, attracted different strategic groups. Patterns in a complex picture show that the village group arena attracted people from weaker groups, such as newcomers, former slaves, the young, women and nobles from rival factions, while the arena constituted by the municipality attracted people belonging to the ruling elites and the rival factions of the emirate. The arena created by the electricity cooperative overlaps with those of the village groups and the municipality, though being closest to that of the municipality. The poorest strata of the population seem generally to be excluded from influence in and the benefits of all three institutions.

The examination of these arenas from a detailed historical perspective has revealed that historical cleavages can be traced back to succession struggles for positions as village chiefs and head of the emirate. These struggles have spread to new arenas and been re-ignited by new institutional dynamics, such as national party politics. The factional cleavages that can be identified have had significant influence in the three arenas under review. In the arena of village groups, cleavages were visible in the sense that, in the majority of groups, membership was structured according to family membership, ethnic origin, age sets and factions, while only a few groups attempted to straddle the two rival factions. The arena of the municipality, on the other hand, was seen as a new and important arena in which the former struggle could be continued, mainly because of its symbolic meaning in terms of regaining the emirate. In the arena of the electricity cooperative, the consensus that was constructed maintained control in the hands of the ruling faction, while at the same time helping maintain a balance between factions, political parties and ethnic groups.

This article has substantiated the argument that different institutions comprise distinct arenas for struggles over resources. It has been shown that these arenas attract actors from different strategic groups, and that the composition of the actors depends to a large degree on the symbolic resources that are at stake. Institutions that, symbolically, compete with chieftaincy institutions (traditional authority) may attract relatives of traditional chiefs (the ruling faction) more than other externally supported institutions. It is suggested that this may be an important element in explaining why the current decentralization process in Burkina Faso seems to sustain traditional relations of power, rather than providing political leverage for weaker groups.

\section{Acknowledgements}

The author gratefully acknowledges the Danish Council for Development Research which funded the research behind this paper and Risø-DTU, the National Laboratory for Sustainable Energy at the Technical University of Denmark, which made it possible for me to write it up. A special thanks to Peter Kragelund for valuable comments throughout the process, and to the two anonymous referees for their comments on an earlier version of this article.

\section{Notes}

1. In a recent essay, Manor (2004) takes some initial steps in this direction by addressing differences between elected councils at lower levels in the political system and user committees responsible for donor-supported infrastructure, such as water, health and education. Manor's main hypothesis is that user committees are 'damaging' decentralization efforts in respect of local elected councils. Manor bases his hypothesis on the observation that, while user committees often control important resources and rest on a questionable democratic mandate, elected councils, which are characterized by more transparent and democratic elections, often lack adequate resources.

2. This understanding of institutions also acknowledges the work of Cleaver (2002), which, through the concept of institutional bricolage, shows that institutions are not built or transferred whole to a new context but rather evolve as a patchwork of bits and pieces of both new and existing institutions.

3. The three institutions are all different from traditional institutions in a number of respects. Some development practitioners have argued that village groups are close to traditional organizations, such as 'age groups', 'working groups' or 'credit groups', which can be found in Burkina Faso among the Fulani and Mossi. These traditional groups, however, are based on rotating aid principles, instead of common ownership of the means of production, as in the case of village 
groups. Common ownership was traditionally practised only within the extended family. (For further discussion, see Ouédraogo 1990, pp. 41-43; Hagberg 2001, p. 54; Nygaard 2006, pp. 196-201.)

4. The terms Fulani (English) and Peul (French) are sometimes used for the entire group of Fulfulde speakers. Here I will employ the Fulfulde terms Fulbe and Rimaïbe to take into account the important socio-political differences between the two ethnic groups. Rimaïbe will be used to indicate non-Fulbe, including caste people and other ethnic groups, who came to the area during colonial times (Irwin 1981, pp. 14, 48). For other ethnic groups I will use the French terms.

5. Hamallism or the Tijanisme de onze grain refers to brotherhoods established by the followers of Cheik Hamahoullah. (For the former and present-day political role of Hamallism in Burkina Faso, see, for example, Traoré 1983; Diallo 1997; Diawara 1999, p. 105; Thébaud 2002).

6. The Sankara revolution from 1983 to 1987 was, in spite of its short duration, of paramount importance for social institutions in the area, and the revolution still reverberates in contemporary dynamics. During the revolution, traditional chiefs were substituted by local revolutionary committees, Comités de Défense de la Révolution (CDR), and popular participation at all levels was encouraged by revolutionary rhetoric (see e.g. Speirs 1991; Tallet 1996).

7. Here the notion of a patron-client relationship refers to 'a relationship of personal dependency, excluding kinship ties, maintained by reciprocal exchanges of favours, between two persons, the patron and the client, who control unequal resources' (Medard 1982, p. 164). A patron-client relationship is a dyadic relationship between a patron and a client. In practice, the client may be the patron of another client, and a multitude of patron-client relationships thus come to constitute a patron-client or clientelist network. A broker is one of a group of actors who serve as mediators of favours between patrons and clients (Boissevain 1974, p. 148).

8. I have taken the concept of development rent, la rente de développement from Olivier de Sardan (1995, p. 160).

9. The widespread use of the word 'community' in terms like community-based organizations (CBOs), community-driven development, community-based forestry and community-based natural resource management implicitly conveys a picture of village organizations representing the whole community (see, e.g., World Bank 2002a, 2002b).

10. The emirate was officially abolished in 1977, but informally the last emir still played an important role in the leadership of the town.

11. The murder of the leading editor of a critical newspaper.

12. This was parallel to what happened in Dori five years earlier, when the former emir was elected mayor.

13. The Danish Government's aid agency.

\section{References}

AMBF (2000), 'Bilan des premiers cinq (5) ans de gestion communale au Burkina Faso 1995 - 2000 : perspectives pour l’avenir. (Résumé),' Report, Association des Maires du Burkina Faso (AMBF).

Berry, S. (1993), No Condition is Permanent, Madison: University of Wisconsin Press.

Bierschenk, T. (1988), 'Development Projects as Arenas of Negotiation for Strategic Groups: A Case Study from Benin,’ Sociologia Ruralis, 28, 146-160.

Bierschenk, T., and Olivier de Sardan, J.-P. (1997), 'ECRIS: Rapid Collective Inquiry for the Identification of Conflicts and Strategic Groups,' Human Organization, 56, 238-244.

Bierschenk, T., and Olivier de Sardan, J.-P. (1998), 'Les arènes locales face à la décentralisation et à la démocratisation,' in Les pouvoirs au village: le Bénin entre démocratisation et décentralisation, eds. T. Bierschenk and J.-P. Olivier de Sardan, Paris: Karthala, pp. 11-52.

Bierschenk, T., and Olivier de Sardan, J.-P. (2003), 'Powers in the Village: Rural Benin between Democratisation and Decentralisation,' Africa, 73, 145-173.

Blundo, G. (1994), 'Le conflit dans l'Entente: coopération et compétition dans les associations paysannes de Koungheul,' in Les associations paysannes en Afrique: organisation et dynamiques, eds. P. Lavigne Delville and J.-P. Jacob, Paris: APAD-Karthala-IUED, pp. 99-120.

Boesen, E. (1999), 'Pulaaku: sur la foulanité,' in Figures peules, eds. R. Botte, J. Boutrais and J. Schmitz, Paris: Karthala, pp. 83-97.

Boissevain, J. (1974), Friends of Friends: Networks, Manipulators and Coalitions, Oxford: Basil Blackwell.

Bourdieu, P. (1977), Outline of a Theory of Practice, Cambridge: Cambridge University Press.

Buijs, P. (1980), 'Programme d'aménagement dans l’ORD du Sahel,' Ouagadougou: Direction du Fonds de Développement Rural.

Buijsrogge, P. (1989), Initiatives paysannes en Afrique de l'Ouest, Paris: Harmattan.

Cleaver, F. (2002), 'Reinventing Institutions: Bricolage and the Social Embeddedness of Natural Resource Management,' European Journal of Development Research, 14, 11-30.

Crehan, K., and Von Oppen, A. (1988), 'Understanding of "Development”: An Arena of Struggle. A Story of a Development Project in Zambia,’ Sociologia Ruralis, XXVIII, 113-145.

Crewe, E., and Harrison, E. (1998), Whose Development? An Ethnography of Aid, London and New York: Zed Books.

Crook, R.C. (2003), 'Decentralisation and Poverty Reduction in Africa: The Politics of Local - Central Relations,' Public Administration and Development, 23, 77-88. 
Crook, R.C., and Manor, J. (1998), Democracy and Decentralisation in South Asia and West Africa: Participation, Accountability and Performance, Cambridge: Cambridge University Press.

Crook, R.C., and Sverrison, A.S. (2001), 'Decentralisation and Poverty-Alleviation in Developing Countries: A Comparative Analysis or, is West Bengal Unique?,' IDS Working Papers, 130, 1-60.

Danida (1999), 'Programme d'appui au Secteur de l’É nergie. Composante B: Sous-composante É lectrification Rurale Décentralisée,' Copenhagen: Danida.

Danida (2001), 'Evaluation: Danish-Burkinabè Development Cooperation,' Copenhagen: Ministry of Foreign Affairs, Danida.

Diallo, H. (1997), 'Moussa Aminou, le “mahdi” de Ouani,' in Le temps des marabouts: itinéraires et stratégies islamiques en Afrique occidentale française 1880-1960, Paris: Karthala, pp. 373-393.

Diawara, M. (1996), 'Mouvement associatif et transformations du champ politique,' in Le Burkina entre révolution et démocratie (1983-1993), eds. R. Otayek, F.M. Sawadogo and J.-P. Guingané, Paris: Karthala, pp. 229-247.

Diawara, M. (1999), 'Réseaux confessionnels de développement, pouvoirs locaux et décentralisation: esquisse d'un modèle d'interprétation général,' in Dieu dans la cité: dynamiques religieuses en milieu urbain ouagalais, ed. R. Otayek, Bordeaux: Centre d'Étude d'Afrique Noire, pp. 17-55.

Donnelly-Roark, P., Ouedraogo, K., and Ye, X. (2001), 'Can Local Institutions Reduce Poverty? Rural Decentralization in Burkina Faso,' World Bank Policy Research Working Paper No. 2677, Environment and Social Development Unit, Africa Region, World Bank.

Elwert, G., and Bierschenk, T. (1988), 'Development Aid as an Intervention in Dynamic Systems: An Introduction,' Sociologia Ruralis, 28, 99-112.

Engberg-Pedersen, L. (2002), 'The Limitations of Political Space in Burkina Faso: Local Organizations, Decentralization and Poverty Reduction,' in In the Name of the Poor: Constructing Political Space for Poverty Reduction, eds. N. Webster and L. Engberg-Pedersen, London, New York: Zed Books, pp. 157-182.

Floquet, A. (1994), 'Dynamique endogène du changement technique et organisation paysanne,' in Les associations paysannes en Afrique: organisation et dynamiques, eds. P. Lavigne Delville and J.-P. Jacob, Paris: APAD-Karthala-IUED, pp. 273-291.

Gentil, D. (1986), Les mouvement coopératifs en Afrique de l'Ouest: intervention de l'Etat ou organisation paysannes?, Paris: Harmattan.

Gueneau, M.-C., and Lecomte, B.J. (1998), Sahel: les paysans dans les marigots de l'aide, Paris: Harmattan.

Hagberg, S. (2001), Poverty in Burkina Faso, Uppsala: ULRiCA, Department of Cultural Anthropology and Ethnology, University of Uppsala.

Hagberg, S. (2002), “"Enough is Enough”: An Ethnography of the Struggle Against Impunity in Burkina Faso,' Journal of Modern African Studies, 40, 217-246.

Hahonou, E.K. (2006), 'En attendant la décentralisation au Niger:clientélisme, factionalisme et culture politique,' unpublished Ph.D. dissertation, l'EHESS.

Hampshire, K. (2002), 'Fulani on the Move: Seasonal Economic Migration in the Sahel as a Social Process,' Journal of Development Studies, 38, 15-36.

Hårsmar, M. (2004), 'The Dual Character of Local Power Structures: Peasant Organisations in Central Burkina Faso,' Paper presented at conference on 'Decentralisation in Practice: Power, Livelihoods and Cultural Meaning in West Africa,' Uppsala 4-6 May 2004.

IBRD (1996), The World Bank Participation Sourcebook, Washington, DC: World Bank.

Irwin, P. (1981), Liptako Speaks: History from Oral Tradition in Africa, Princeton: Princeton University Press.

Jacob, J.-P. (1994), 'Gouvernance, imputation, redondance: réflexions sur la multiplicité des intervenants et la multiplication des organisations paysannes,' in Les associations paysannes en Afrique: organisation et dynamiques, eds. P. Lavigne Delville and J.-P. Jacob, Paris: APAD-Karthala-IUED, pp. 255-270.

Jütting, J., Corsi, E., Kauffmann, C., McDonnell, I., Osterrieder, H., Pinaud, N., and Wegner, L. (2005), 'What Makes Decentralisation in Developing Countries Pro-poor?,' European Journal of Development Research, 17, 626-648.

Laurent, P.-J. (1998), Une association de développement en pays mossi: le don comme ruse, Paris: Karthala. Lavigne

Delville, P. (1992), 'Groupements villageois et processus de transition,' Cah. Sci. Hum., 28, 327-343. Long, N. (2001),

Development Sociology: Actor Perspectives, London: Routledge.

Loyara, T., Ouedraogo, O.P., and Sanou, P. (2000), 'Monographie de la Commune de Sebba,' Report, Commission Nationale de la Décentralisation, Burkina Faso.

Lund, C. (1999), 'A Question of Honour: Property Disputes and Brokerage in Northern Burkina Faso,' Africa, 69, 575-595.

Maïga, S.A. (2004), 'Élections municipales à Diébougou,' in Diébougou, une petite ville du Burkina Faso, ed. K. Werthman, Mainz: Department of Anthropology and African Studies, Johannes Gutenberg University, pp. $81-92$.

Manor, J. (2004), 'User Committees: A Potentially Damaging Second Wave of Decentralization?,' 
European Journal of Development Research, 16, 192-213.

Massé, R. (2004), 'Comment se sont-ils électrifiés? Deux études de cas de politique nationale d'électrification: France, Etats-Unis,’ Études et Travaux, série en ligne: Les éditions du Gret, www.gret.org.

McCall, D., Fleming, A.P., Koussoube, I., and McPherson, L. (1986), 'Burkina Faso: Integrated Rural Development Projects in Seguenega and Dori Departments,' Aid-Project-Impact-Evaluation-Report no. 61, Washington, DC: Bureau for the Near East, Agency for International Development (AID).

Medard, J.-F. (1982), 'The Underdeveloped State in Tropical Africa: Political Clientelism or Neopatrimonialism?,' in Private Patronage and Public Power: Political Clientelism in the Modern State, ed. C. Clapham, London: Frances Pinter, pp. 162-192.

Michener, V.J. (1998), 'The Participatory Approach: Contradiction and Co-option in Burkina Faso,' World Development, 26, 2105-2118.

Mongbo, R. (1994), 'La dynamique des organisations paysannes et la négociation quotidienne du "développement rural” à la base: une étude de cas au Benin,' in Les associations paysannes en Afrique: organisation et dynamiques, eds. P. Lavigne Delville and J.-P. Jacob, Paris: APAD-Karthala-IUED, pp. 135-154.

Mosse, D. (2001), “"People’s Knowledge”, Participation and Patronage: Operations and Representations in Rural Development,' in Participation: The New Tyranny?, eds. B. Cooke and U. Kothari, London, New York: Zed Books, pp. 16-35.

Nijenhuis, K. (2003), 'Does Decentralization Serve Everyone? The Struggle for Power in a Malian Village,' European Journal of Development Research, 15, 67-92.

Nygaard, I. (2006), 'Institutions; Invented, Reinvented and Changed: A Challenge for Development Intervention,’ unpublished Ph.D. dissertation, Roskilde University.

Olivier de Sardan, J.-P. (1995), Anthropologie et développement: essai en socio-anthropologie du changement social, Paris: APAD-Karthala.

Olivier de Sardan, J.-P. (2004), 'Local Powers Awaiting Decentralisation (Niger),' paper presented at conference on 'Decentralisation in Practice: Power, Livelihoods and Cultural Meaning in West Africa,' Uppsala, May 4-6.

Otayek, R. (1995), 'Les élections municipales du 12 février 1995 au Burkina Faso,' Politique Africaine, 58, 135142.

Otayek, R. (1999), 'Dynamiques religieuses et gestion communale par temps de décentralisation: le religieux comme analyseur de la politique urbaine,' in Dieu dans la cité: dynamiques religieuses en milieu urbain ouagalais, ed. R. Otayek, Bordeaux: Centre d'Étude d'Afrique Noire, 17-55.

Ouédraogo, B.L. (1990), Entreaide villageoise et développement: groupements paysans au Burkina Faso, Paris: Harmattan.

Ouédraogo, H.M.G. (2003), 'Decentralisation and Local Governance: Experiences from Francophone West Africa,' Public Administration and Development, 23, 97-103.

Platteau, J.P. (2004), 'Monitoring Elite Capture in Community Driven Development,' Development and Change, $35,223-246$.

Puget, F. (1999), Femmes peules du Burkina Faso: stratégies féminines et développement rural, Paris: Harmattan.

Ribot, J. (1999), 'Decentralisation, Participation and Accountability in Sahelian Forestry: Legal Instruments of Political-Administrative Control,' Africa, 69, 23-43.

Rondinelli, D.A. (1981), 'Governmental Decentralization in Comparative Theory and Practice in Developing Countries,' International Review of Administrative Science, 47, 133-147.

Sawadogo, R.A. (2001), L’État africain face à la décentralisation, Paris: Karthala.

Scott, W.R. (1995), Institutions and Organizations, Thousand Oaks, CA: Sage Publications.

Soumane, B., and Bonou, Y.V. (2001), 'Étude pour la recherche d'un compromis autour d'une commune rurale type au Burkina Faso: cas de la région Sahel,' Report, Ouagadougou: Commission Nationale de la Décentralisation.

Speirs, M. (1991), 'Agrarian Change and the Revolution in Burkina Faso,' African Affairs, 90, 89 - 110. Tallet, B. (1996), '1983 - 1993: Dix ans de politique agricole,' in Le Burkina entre re'volution et de'mocratie (1983 1993), eds.R. Otayek, F.M. Sawadogo and J.-P. Guingane', Paris: Karthala, pp. 119 - 132.

Thébaud, B. (2002), Foncier pastoral et gestion de l'espace au Sahel: Peuls du Niger oriental et du Yagha burkinabé, Paris: Karthala.

Traoré, A. (1983), Cheikh Hamahoullah: homme de foi et résistant, Paris: Maisonneuve et Larose.

Van der Vleuten, E. (1998), 'Electrifying Denmark: A Symmetrical History of Central and Decentral Electricity Supply Until 1970,' PhD dissertation, History of Science Department, University of Aarhus.

Vedeld, T. (2003), 'Democratic Decentralisation and Poverty Reduction: Exploring the Linkages,' Forum for Development Studies, 159-203.

White, S.C. (1996), 'Depoliticising Development: The Uses and Abuses of Participation,' Development in Practice, 6, 6-15. 
World Bank (2002a), Community Driven Development: A Vision of Poverty Reduction through Empowerment, Washington, DC: World Bank.

World Bank (2002b), Community Driven Development; from Vision to Practice: A Technical Sourcebook, Washington, DC: World Bank. 